\title{
DISPENSASI KAWIN AKIBAT HAMIL DI LUAR PERKAWINAN DAN DAMPAKNYA PADA FORMULASI PIDANA ZINA DALAM RANCANGAN KITAB UNDANG-UNDANG HUKUM PIDANA
}

\author{
Thogu Ahmad Siregar \\ Program Magister Ilmu Hukum, Fakultas Hukum, Universitas Gadjah Mada \\ email: thogu.a.s@mail.ugm.ac.id \\ Petrus Richard Sianturi \\ Program Magister Ilmu Hukum, Fakultas Hukum, Universitas Gadjah Mada \\ email: richardsianturi@mail.ugm.ac.id
}

disampaikan 21/01/2020 - di-review 20/06/19 - diterima 03/12/2020

DOI: $10.25123 /$ vej.3702

\begin{abstract}
Data shows a high number of under-age or child marriages Indonesia. A related phenomenon is number of dispensation requested to the court to conduct marriage in case one or both couples are under age. Reason for this practice may be escape route from poverty, or as a more common justification to prevent sexual intercourse outside marriage (fornication) considered per se immoral. Meanwhile, drafter of the Indonesian Criminal Code decides to criminalize sexual intercourse outside marriage. The author, using a descriptive analytical approach, suggest that, at the abstract level, a contradiction exist between the rule of allowing the granting of court dispensation and the rule purporting to criminalize sex outside marriage. Dispensation, in the final analysis, may be used to decriminalize sex between under age couples.
\end{abstract}

Keywords: decriminalization of sexual intercourse between under age couples, marriage dispensation, fornication

\begin{abstract}
Abstrak
Kejadian pernikahan anak di bawah umur di Indonesia cukup tinggi. Ini berkorelasi pula dengan tingginya pengajuan permohonan dispensasi kawin yang diajukan kehadapan Pengadilan. Faktor pendorong pernikahan anak di bawah umur adalah ikhtiar keluar dari kemiskinanan atau juga sering diungkap sebagai alasan mencegah terjadinya seks di luar ikatan pernikahan yang seketika dipandang amoral. Sementara itu, Rancangan Kitab Undang-Undang Hukum Pidana Indonesia merumuskan hubungan seks di luar ikatan perkawinan sebagai perzinahan yang diancam sanksi pidana. Penelitian ini yang dilakukan dengan pendekatan deskriptif-analitis menemukan adanya kemungkinan pertentangan, pada tataran prinsip atau abstrak, antara aturan pemberian dispensasi nikah bagi pasangan di bawah umur dengan aturan tentang larangan hubungan seks di luar ikatan perkawinan dalam RKUHP. Dalam hal ini, pemberian dispensasi dapat dimaknai sebagai alasan penghapus pidana atau alasan pemaaaf.
\end{abstract}

Kata Kunci: alasan penghapus pidana, perkawinan anak di bawah umur, dispensasi kawin, pidana zina 


\section{Pendahuluan}

Indonesia, melalui pemerintah dan Dewan Perwakilan Rakyat (DPR), sedang menyusun Rancangan Kitab Undang-Undang Hukum Pidana (RKUHP). Naskah draf RKUHP sebenarnya sudah disusun cukup lama. ${ }^{1}$ Saat ini, seperti disampaikan baik oleh pihak eksekutif dan legislatif, pembahasan draf terakhir sudah mencapai tahap final. Salah satu perbuatan yang dikriminalisasi ${ }^{2}$ adalah terkait perzinaan. Terdapat lima subyek hukum yang dapat dikualifikasi bertanggung jawab atas tindak pidana jika merujuk pada Pasal 417 ayat (1) RKUHP versi 14 September 2019. Pasal 417 ayat (1) mengatur bahwa "Setiap orang yang melakukan persetubuhan dengan orang yang bukan suami atau istrinya dipidana karena perzinaan dengan pidana penjara paling lama 1 (satu) tahun atau denda Kategori II".

Unsur utama dalam delik ini adalah pada bagian "persetubuhan" dan "orang yang bukan suami atau istrinya”. Dalam penjelasan Pasal 417 ayat (1) dinyatakan bahwa yang dimaksud dengan "bukan suami atau istrinya" adalah pertama, laki-laki yang berada dalam ikatan perkawinan melakukan persetubuhan dengan perempuan yang bukan istrinya. Kedua, perempuan yang berada dalam ikatan perkawinan melakukan persetubuhan dengan laki-laki yang bukan suaminya. Ketiga, laki-laki yang tidak dalam ikatan perkawinan melakukan persetubuhan dengan perempuan, padahal diketahui bahwa perempuan tersebut berada dalam ikatan perkawinan. Keempat, perempuan yang tidak dalam ikatan perkawinan melakukan persetubuhan dengan laki-laki, padahal diketahui bahwa laki-laki tersebut berada dalam ikatan perkawinan, atau kelima, laki-laki dan perempuan yang masing-masing tidak terikat dalam perkawinan melakukan persetubuhan.

Pasal ini sendiri memunculkan perdebatan antara mereka yang berpendapat bahwa perzinaan bukan hanya melanggar nilai-nilai dalam norma

1 Yang dimaksud draf RKUHP dalam penelitian ini adalah draf RKUHP per tanggal 14 September 2019.

2 Kriminalisasi dimaksud berada dalam ranah kebijakan hukum pidana (penal policy) yang berarti bahwa adanya perbuatan yang sebelumnya tidak dikualifikasi sebagai kejahatan atau tindak pidana kemudian diformulasi menjadi bentuk kejahatan atau tindak pidana. 
agama dan sosial, tetapi juga mengganggu ketertiban di masyarakat dengan mereka yang melihat adanya potensi pelanggaran hak-hak privasi warga masyarakat. Penelitian ini fokus membahas unsur penjelasan Pasal 417 ayat (1) huruf e dimana perzinaan dapat dikenakan kepada mereka, laki-laki dan perempuan, di luar ikatan perkawinan yang melakukan persetubuhan. Dasar hukum perkawinan sebagai ikatan keperdataan di Indonesia diatur melalui Undang-Undang Nomor 1 tahun 1974 tentang Perkawinan (selanjutnya ditulis UU No. 1/1974) juncto Undang-Undang Nomor 16 tahun 2019 tentang Perubahan terhadap Undang-Undang No. 1 tahun 1974 tentang Perkawinan (selanjutnya ditulis UU No. 16/2019).

Konsep perkawinan dalam UU No. 1/1974 jo. UU No. 16/2019 adalah ikatan antara laki-laki dan perempuan yang disahkan melalui hukum negara dan diakui dalam nilai-nilai agama. Prasyarat utama dalam perkawinan adalah batas umur minimum bagi laki-laki dan perempuan. Sebelumnya, UU No. 1/1974 mengatur bahwa batas umur minimum bagi laki-laki untuk menikah adalah 19 tahun dan bagi perempuan adalah 16 tahun. Saat ini, pasca diberlakukannya UU No. $16 / 2019$, batas umur minimum perkawinan bagi perempuan ditingkatkan menjadi 19 tahun, artinya sama dengan batas umur minimum bagi laki-laki. Batas usia minimum ini dianggap sebagai batasan legal untuk menyatakan bahwa lakilaki dan perempuan yang ingin melangsungkan pernikahan telah dianggap dewasa. Secara a contrario, batas umur minimum menjadi batasan legal bagi setiap laki-laki dan perempuan bukan tergolong "anak" untuk melangsungkan perkawinan.

Meskipun batas umur minimum untuk melangsungkan perkawinan diatur, di Indonesia terdapat konsep dispensasi kawin yang diberikan kepada laki-laki dan/atau perempuan yang masih berusia di bawah umur minimum sebagaimana diatur dalam UU No. 01/1974 jo. UU No. 16/2019. Terdapat permohonanpermohonan untuk diperbolehkannya melangsungkan perkawinan pasca terjadinya persetubuhan antara laki-laki dan perempuan di bawah umur akibat "hal-hal penting" seperti adanya kehamilan di luar ikatan perkawinan. Dalam ranah hukum keperdataan, secara khusus merujuk pada hukum perkawinan, 
terhadap fakta ini dapat diatasi dengan pengajuan permohonan dispensasi kawin oleh para pihak kepada Pengadilan Agama (bagi masyarakat Muslim) ${ }^{3}$ atau Pengadilan Negeri (bagi masyarakat non-Muslim) ${ }^{4}$. Dispensasi kawin akan diberikan berdasarkan dikabulkannya permohonan oleh pengadilan yang berwenang untuk memberikan penetapan. Konsep dispensasi kawin sendiri sudah lazim dilakukan di Indonesia. Persoalannya bukan pada konsep dispensasi kawin, tetapi jika dikaitkan dengan formulasi pidana zina dalam RKUHP sebagaimana sudah disinggung sebelumnya, apakah konsep dispensasi kawin masih dapat diberlakukan. Sebaliknya, dengan diformulasikannya persetubuhan antara lakilaki dan perempuan di luar ikatan perkawinan sebagai tindak pidana, apakah melalui konsep dispensasi kawin dapat menjadi alasan penghapus pidana bagi mereka yang melanggar pasal tentang delik perzinaan.

Penelitian ini adalah penelitian yuridis-normatif dengan pendekatan analitis-deskriptif. Metode penelitian yuridis-normatif adalah penelitian yang difokuskan untuk mengkaji penerapan kaidah-kaidah atau norma-norma dalam hukum positif. ${ }^{5}$ Adapun pendekatan analitis-deskriptif akan membantu untuk menelaah lebih mendalam atas ketentuan-ketentuan yang tertulis dalam normanorma hukum positif tersebut. ${ }^{6}$ Bahan utama penelitian ini dilakukan dengan penelusuran aturan hukum yang mengatur terkait dengan dispensasi kawin dalam UU No. 1/1974 jo. UU No. 16/2019 dan formulasi pidana zina dalam RKUHP. Analisis terhadap aturan-aturan hukum tentang konsep dispensasi kawin tersebut dilakukan dengan tinjauan pustaka dari literatur terkait asas dan teori hukum perkawinan. Dalam penelitian ini, pembahasan mengenai kaitan konsep dispensasi kawin itu dengan formulasi pidana zina pada RKUHP ditempatkan dalam pembahasan kebijakan hukum pidana (penal policy).

3 UU No. 1/1974 jo. pasal 49 dan 50 Undang-Undang No. 3 tahun 2006 tentang Perubahan atas Undang-Undang No. 7 tahun 1989 tentang Peradilan Agama.

4 Petunjuk Mahkamah Agung No. M.A/Pemb/0807/75 tentang Petunjuk-Petunjuk MA Mengenai Pelaksanaan Undang-Undang Nomor 1 Tahun 1974 dan Peraturan Pemerintah Nomor 9 tahun 1975.

5 Ibrahim, Teori dan Metodologi Penelitian Hukum Normatif, Bayumedia Publishing, Malang, 2013, hlm., 295.

6 Marzuki, Penelitian Hukum (Edisi Revisi), Prenadamedia Group, Jakarta, 2015, hlm., 142. 
Persoalan mendasar yang ingin dibahas dalam penelitian ingin menjawab dua rumusan masalah sebagai berikut: bagaimana konsep dispensasi kawin di Indonesia untuk kondisi kehamilan di luar ikatan perkawinan?, dan bagaimana konsep dispensasi kawin yang ingin melindungi kepentingan keperdataan orangperorangan mempengaruhi formulasi pidana zina yang menekankan pada kepentingan publik di dalam RKUHP?

\section{Perkawinan dan Tingkat Perkawinan Anak di Indonesia}

Perkawinan di Indonesia diatur dalam UU No. 1/1974 jo. UU No. 16/2019. Pasal 1 UU No. 1/1974 menyebutkan bahwa "Perkawinan ialah ikatan lahir batin antara seorang pria dengan seorang wanita sebagai suami istri dengan tujuan membentuk keluarga (rumah tangga) yang bahagia dan kekal berdasarkan Ketuhanan Yang Maha Esa". Penekanan pada kata "seorang" diperjelas dengan ketentuan pada Pasal 3 yang berbunyi:

"Pada azasnya dalam suatu perkawinan seorang pria hanya boleh mempunyai seorang istri. Seorang wanita hanya boleh mempunyai seorang suami". Dengan demikian, regulasi perkawinan di Indonesia pada dasarnya menganut asas monogami. ${ }^{7}$

Batasan umur adalah hal krusial dalam proses perkawinan dapat dilaksanakan untuk mempertimbangkan kematangan biologis dan psikologis. Penelitian Pusat Studi Wanita Universitas Islam Negeri Syarif Hidayatullah, Jakarta, disebutkan bahwa rata-rata usia ideal untuk melangsungkan perkawinan berkisar umur 19,9 tahun untuk perempuan, dan 23,4 tahun untuk laki-laki. Pertimbangan umur dimaksud bukan hanya untuk memperhatikan kematangan biologis tetapi terkait pula dengan kematangan psikologis dan kondisi sosial. Ahmad Tholabi Kharlie menyebutkan kematangan umur ini merupakan akumulasi dari kesiapan fisik, ekonomi, sosial, mental atau kejiwaan, agama, dan budaya. ${ }^{8}$

Selain itu, aspek lain yang perlu dipertimbangkan adalah perihal proses kehamilan. Umur mempengaruhi potensi meninggalnya ibu dan/atau janinnya

7 Meskipun demikian, UU No. 1/1974 memberikan peluang dilakukannya poligami oleh pihak suami sebagaimana diatur dalam pasal 3, 4 dan 5. Tidak dibahas lebih lanjut pada penelitian ini.

8 Kharlie, Hukum Keluarga Indonesia, Sinar Grafika, Jakarta, 2015, hlm., 204. 
dalam hal ibu melahirkan terlalu awal atau sebaliknya, terlalu lambat. Perempuan yang secara fisik belum matang akan menghadapi bahaya lebih besar ketika melahirkan dan besar kemungkinan akan melahirkan anak yang lemah dibandingkan perempuan yang berumur di atas dua puluh atau yang sudah tergolong sebagai perempuan dewasa. ${ }^{9}$

Terkait dengan umur, UU No. 16/2019 telah mengubah batas umur menikah antara laki-laki dan perempuan yang terdapat pada Pasal 7 UU No. 1/1974 dari ketentuan awalnya minimum umur 19 tahun untuk laki-laki dan 16 tahun untuk perempuan menjadi minimum umur 19 tahun juga untuk pihak perempuan. Konsederasi perubahan batas umur minimum bagi perempuan salah satunya disebabkan adanya ketentuan yang saling bertentangan antara UU No. 1/1974 dengan Undang-Undang Nomor 35 tahun 2014 tentang Perubahan atas UU No. 23 tahun 2002 tentang Perlindungan Anak. Adapun bunyi dari Pasal 7 UU Nomor 16/2019, sebagai berikut:

1. "Perkawinan hanya diizinkan apabila pria dan wanita sudah mencapai umur 19 (sembilan belas) tahun.

2. Dalam hal terjadi penyimpangan terhadap ketentuan umur sebagaimana dimaksud pada ayat (1), orang tua pihak pria dan/atau orang tua pihak wanita dapat meminta dispensasi kepada pengadilan dengan alasan sangat mendesak disertai bukti-bukti pendukung yang cukup.

3. Pemberian dispensasi oleh pengadilan sebagaimana dimaksud pada ayat (2) wajib mendengarkan pendapat kedua belah calon mempelai yang akan melangsungkan perkawinan.

4. Ketentuan-ketentuan mengenai keadaan seorang atau kedua orang tua calon mempelai sebagaimana dimaksud dalam Pasal 6 ayat (3) dan ayat (41 berlaku juga ketentuan mengenai permintaan dispensasi sebagaimana dimaksud pada ayat (2) dengan tidak mengurangi ketentuan sebagaimana dimaksud dalam Pasal 6 ayat (6)."

Pasal 7 UU No. 16/2019 yang telah mengubah batas minimum umur menikah ini dapat diapresiasi untuk menekan terjadinya perkawinan antara lakilaki dan perempuan di bawah umur yang cukup tinggi di Indonesia. Persoalan yang menjadi objek penelitian ini adalah meskipun telah dilakukan perubahan untuk batas minimum umur bagi perempuan untuk melangsungkan perkawinan,

$9 \quad$ Id. 
namun secara hukum masih diperbolehkan adanya permohonan dan penetapan dispensasi kawin sebagaimana diatur dalam Pasal 7 ayat (2). Sebelum sampai pada pembahasan teroritis, maka perlu disampaikan data berikut ini. Pada 2014, Badan Peradilan Agama mencatat sebanyak 11.774 anak Indonesia melakukan pernikahan dini. ${ }^{10}$

Data United Nations Development Economic and Social Affairs tahun 2016 menunjukan Indonesia sebagai negara ke-37 dengan jumlah perkawinan anak terbanyak di dunia yaitu sebesar 34\%. Sedangkan untuk level Asia Tenggara, Indonesia berada di urutan kedua setelah Kamboja yaitu sebesar 23\% (ilustrasi: satu dari empat perempuan sudah menikah sebelum memasuki umur 18 tahun). Mengingat resiko pernikahan umur anak pada generasi penerus bangsa, laju pernikahan umur anak di Indonesia perlu diredam. ${ }^{11}$

Untuk memaparkan data tentang pernikahan dini yang terjadi di Indonesia, Badan Pusat Statistik dan UNICEF Indonesia telah melakukan penelitian terkait dengan usia anak di Indonesia dengan melihat dari aspek pendidikan, lokasi geografis, dan status ekonomi, dimana dalam penelitian itu menampilkan angka prevalensi di tingkat provinsi, kabupaten/kota, dan kecamatan, yang didasarkan pada Sensus Ekonomi Nasional (SUSENAS) periode 2008-2012 dan sensus penduduk tahun 2010. Data SUSENAS menganalisis sampel perempuan pernah menikah usia 20-24 tahun yang pernah menikah sebelum umur 18 tahun.

Terdapat delapan temuan sebagai hasil dari analisi data di atas, yaitu:12

1. Prevalensi perkawinan usia anak di Indonesia tidak mengalami perubahan dan tetap tinggi. Perkawinan usia anak di Indonesia masih berada di angka yang tinggi dengan satu dari empat anak perempuan menikah sebelum mencapai kedewasaan. Data dari SUSENAS menunjukkan bahwa sejak 2008 angka perkawinan usia anak relatif stabil di sekitar 25\%. Angka tersebut sedikit menurun dari 27,4\% di tahun 2008 ke 22,8\% di tahun 2015.

\footnotetext{
10 Judiasih, et al, Perkawinan Bawah Umur di Indonesia, Refika, Bandung, 2018, hlm., 5.

11 Badan Kependudukan dan Keluarga Berencana Nasional (BKKBN), https://www. bkkbn.go.id/detailpost/perkawinan-anak-di-indonesia-masih-tinggi, diakses tanggal 14 Januari 2020.

12 Judiasih et al, supra no. 10, hlm., 15.
} 
2. Angka perkawinan usia anak tertinggi terjadi pada anak perempuan yang berusia 16 dan 17 tahun. Pernikahan pada usia 16 dan 17 tahun tidak mengalami perubahan yang signifikan dari tahun 2008 dengan 20,2\% sampai tahun 2015 dengan 19,3\%.

3. Perkawinan usia anak dan capaian pendidikan saling berkaitan. Data persentase perempuan yang menikah di bawah umur 18 tahun dan perempuan yang menikah di atas 18 tahun pada tahun 2015 menunjukkan bahwa anak perempuan yang menikah di bawah 18 tahun berpeluang enam kali lebih besar untuk tidak menyelesaikan pendidikan menengah atas dibandingkan anak perempuan yang menikah di atas usia 18 tahun. Hal ini mengindikasikan bahwa sekolah menengah atas dapat mendorong penundaan pernikahan sampai anak perempuan tersebut mencapai kedewasaan.

4. Walau kemiskinan membuat anak perempuan lebih rentan terhadap perkawinan usia anak, praktik ini diterima secara sosial dan budaya di seluruh tingkat ekonomi. Analisis menunjukkan perkawinan usia anak berkaitan erat dengan daerah pedesaan, kondisi rumah yang tidak layak, dan rumah tangga dengan tingkat pengeluaran yang rendah. Semua kategori ini berkaitan erat dengan kemiskinan. Perkawinan usia anak berpeluang terjadi 1,5 kali lebih besar di daerah pedesaan dibandingkan di daerah perkotaan $(27,1 \%$ di daerah pedesaan dan $17,1 \%$ di daerah perkotaan) dan perbedaan ini tidak mengalami perubahan sejak tahun 2008.

5. Angka perkawinan usia anak dan remaja yang sangat tinggi ditemukan di daerah-daerah terpencil di seluruh Indonesia.

6. Akses pada tenaga kesehatan yang terampil saat melahirkan dan intervensi dini bayi lebih baik untuk anak perempuan yang menikah setelah usia 18 tahun. Anak yang menikah di bawah 18 tahun berpeuang lebih besar untuk tidak menerima bantuan dari tenaga kesehatan professional saat melahirkan. Perempuan yang di bawah 18 tahun juga berpeluang besar untuk tidak memberikan air susu ibu (ASI) kepada bayinya dalam waktu satu jam setelah melahirkan. 
7. Anak perempuan yang menikah sebelum usia 18 tahun berpeluang untuk tidak mendapatkan manfaat perlindungan sosial yang diarahkan untuk rumah tangga miskin. Analisis ini menyatakan bahwa anak perempuan yang menikah sebelum usia 18 tahun berpeluang lebih besar untuk tidak masuk dalam kategori miskin di dalam data nasional sehingga mereka tidak berhak untuk mendapatkan Kartu Perlindungan Sosial (KPS). Hanya 18,2\% anak perempuan yang menikah di bawah 18 tahun memiliki KPS. Hal ini menunjukkan bahwa perempuan yang menikah di bawah 18 tahun tidak terdeteksi oleh radar kemiskinan.

8. Anak perempuan yang menikah sebelum usia 18 tahun cenderung ikut serta dalam sektor pertanian dan menjadi bagian dari sektor ekonomi informal. Data menunjukkan bahwa perempuan yang menikah di bawah 18 tahun lebih banyak berkerja di sektor informal (68,6\%) dibandingkan sektor formal (31,4\%) di tahun 2015.

Tiga faktor penyebab terjadinya pernikahan dini di Indonesia adalah pendidikan, hamil di luar ikatan perkawinan, dan ekonomi.13 Faktor pendidikan yang dimaksud adalah terkait cara pandang masyarakat yang sangat sederhana bahkan cenderung salah dalam memandang perkawinan. Kondisi pendidikan yang rendah ini berdampak pada lahirnya cara pandang yang sempit terhadap perkawinan. ${ }^{14}$ Faktor kehamilan di luar ikatan perkawinan, atau married by accident akibat pergaulan bebas. Secara psikologis dan biologis, remaja mengalami perubahan dalam banyak aspek diri termasuk pada perubahan sikap dan tingkah laku, seperti mulai memperhatikan penampilan diri. ${ }^{15}$ Perubahan itu juga mendorong, secara alamiah, ketertarikan terhadap lawan jenis, yang dalam beberapa kasus tertentu berlanjut pada hubungan persetubuhan yang belum

13 Kharlie, supra no. 6, hlm., 211. Sebagai perbandingan, di negara Mesir terdapat beberapa faktor seorang perempuan melakukan perkawinan dini, di antaranya: a. Faktor agama atau moral, yaitu anggapan menghalangi perkawinan dini adalah perbuatan yang salah; b. Faktor ekonomi, bahwa dalam masyarakat pedesaan seorang istri yang menikahi laki-laki akan mampu melayani suaminya; dan c. Faktor budaya, yaitu demi menghormati dan menjaga keperawanan perempuan.

14 Id.

15 Id. 
seharusnya dilakukan tanpa adanya ikatan perkawinan. Kehamilan yang disebabkan oleh hubungan itu menjadi alasan untuk melaksanakan perkawinan.

Tabel 1: Persentase perkawinan perempuan di bawah umur tahun 2008-2015

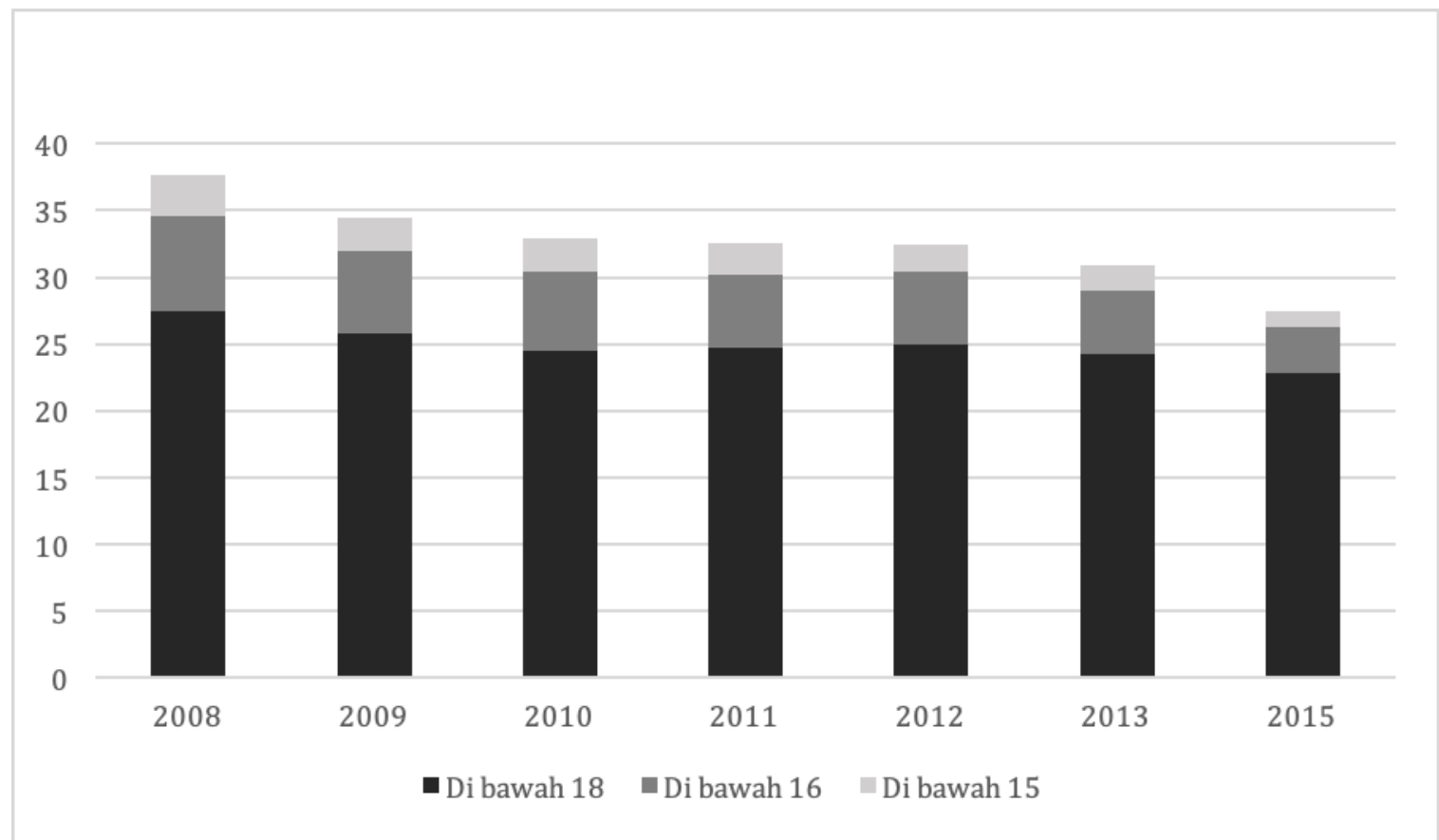

Sumber: Judiasih, et al, Perkawinan Bawah Umur di Indonesia, Refika, Bandung, 2018, hlm., 8

Faktor ekonomi juga mempengaruhi tingginya angka perkawinan anak di bawah umur. Salah satu dampak dari kondisi ekonomi yang lemah adalah orang tua tidak bisa menyekolahkan anaknya ke jenjang yang lebih tinggi, sehingga orang tua beranggapan bahwa menikahkan anaknya merupakan salah satu solusi untuk meringankan beban hidup keluarga. Kondisi demikian membuat orang tua, memberikan izin atau bahkan yang memiliki inisiatif untuk mengajukan permohonan dispensasi kawin ke pengadilan. ${ }^{16}$

\section{Konsep Dispensasi Kawin}

Dispensasi kawin dalam hukum perkawinan Indonesia dan praktik peradilan sangat sering terjadi. Berdasarkan hasil penetapan Pengadilan Agama Yogyakarta dari tahun 2010-2015, terdapat sebanyak 248 perkara permohonan dispensasi

16 Nur Aisyah, Dispensasi Pernikahan di Bawah Umur pada Masyarakat Islam di Kabupaten Bantaeng, 4, Jurisprudentie. 172, 181, 2017, hlm., 172, 181. 
kawin, yaitu 34 perkara tahun 2010, 56 perkara tahun 2011, 37 perkara tahun 2012, 44 perkara tahun 2013, 41 perkara tahun 2015 dan 36 perkara tahun 2015. Dari keseluruhan permohonan dispensasi tersebut, alasan yang paling banyak diajukan adalah karena kondisi kehamilan perempuan di luar ikatan perkawinan. Dari 248 perkara yang diputus oleh Pengadilan Agama Yogyakarta pada tahun 2010-2015 terdapat sebanyak 174 (72\%) perkara dengan alasan permohonan dispensasi kawin karena kondisi kehamilan perempuan di luar ikatan perkawinan sebagaimana yang dipublikasikan di laman online Pengadilan Agama Yogyakarta. ${ }^{17}$

Selain itu, Pengadilan Agama Ponorogo mencatat terdapat 61 remaja terdiri dari 30 perempuan dan 31 laki-laki mengajukan dispensasi nikah selama Januari-September 2019. Dari total 30 anak perempuan yang mengajukan dispensasi menikah tersebut, 20 di antaranya mengemukakan bahwa alasan utama pengajuan dispensasi kawin adalah karena sudah dalam keadaan hamil akibat persetubuhan di luar ikatan perkawinan. ${ }^{18}$ Di wilayah Jawa Barat, Pengadilan Agama Kabupaten Subang mencatat bahwa dalam satu bulan, rata-rata terdapat lima hingga tujuh anak usia 16 tahun ke bawah sudah melakukan perkawinan atas dispensasi kawin. Sejak 2016 hingga 2018, rata-rata terjadi perawinan di bawah umur sebanyak 71 kasus per tahun. Dalam kurun waktu itu, terdapat sebanyak 213 perkawinan di bawah umur. ${ }^{19}$ Berdasarkan keterangan dari panitera Pengadilan Agama Subang, H Deden Nazmudin, permohonan dispensasi kawin ke pengadilan didominasi karena adalah hamil di luar ikatan perkawinan. ${ }^{20}$

17 Nurul Inayah, Penetapan Dispensasi Nikah Akibat Hamil di Luar Nikah di Pengadilan Agama Yogyakarta Tahun 2010-2015 (Analisis Hukum Acara Peradilan Agama), 10, Al-Ahwal, 178, $179,2017$.

18 Menurut pegawai Humas Pengadilan Agama Ponorogo, Misnan Maulana, selain alasan kehamilan, alasan lainnya adalah kekhawatiran orang tua. kata Humas Pengadilan Agama Ponorogo. Jatimnow.com, https://jatimnow.com/baca-20460-hamil-duluan-puluhan-abg-diponorogo-ajukan-dispensasi-nikah, diakses pada tanggal 10 Januari, 2020.

19 Tahun 2016 sebanyak 71 kasus, tahun 2017 sebanyak 80 kasus dan tahun 2018 sebanyak 62 kasus. Pasundanekspres.co, https://pasundanekspres.co/2019/03/213-anak-di-subangsudah-menikah-dispensasi-karena-hamil-duluan, diakses tanggal 6 Januari, 2020.

20 Id. 
Selain di Pulau Jawa, Pengadilan Agama Bolaang Uki, Kabupaten Bolaang Mogondow Selatan (Bolsel), Sulawesi Utara mencatat bahwa sejak awal Januari 2019 sampai dengan Januari 2020 telah mendapatkan 45 pengajuan permohonan dispensasi kawin. Dari 45 perkara permohonan itu, terdapat 15 sidang Isbat Nikah. Sedangkan 30 pengajuan permohonan lainnya adalah permohonan dispensasi kawin. Alasan pengajuan permohonan juga didominasi oleh kondisi pihak perempuan yang sudah hamil akibat persetubuhan di luar ikatan perkawinan. $^{21}$

Pasca diundangkannya UU No. 16/2019 pada 15 November 2019 lalu, pengajuan permohonan dispensasi kawin meningkat secara signifikan. Data pengajuan permohonan dispensasi kawin pada Pengadilan Agama se-Jawa Tengah misalnya, meningkat sebesar 286,2\% atau penambahan sebanyak 1016 permohonan dengan perbandingan data dari bulan Oktober 2019 sebanyak 355 perkara dan pada akhir November 2019 terdapat sebanyak 1371 perkara. Hal tersebut diungkap oleh Ketua Pengadilan Tinggi Agama Semarang, Bahruddin Muhammad, saat memberikan sambutan pada acara Sosialisasi Peraturan Mahkamah Agung Nomor 5 Tahun 2019 tentang Pedoman Mengadili Perkara Dispensasi Kawin pada 17 Desember 2019 di hotel Grasia Semarang. ${ }^{22}$

Kondisi demikian dimungkinkan sebab dalam Pasal 7 ayat (2) UU No. 1 tahun 1974 dinyatakan bahwa "Dalam hal terjadi penyimpangan terhadap ketentuan umur sebagaimana dimaksud pada ayat (1), orang tua pihak pria dan/atau orang tua pihak wanita dapat meminta dispensasi kepada pengadilan dengan alasan sangat mendesak disertai bukti-bukti pendukung yang cukup". Pasal ini memungkinkan perkawinan dilakukan oleh laki-laki dan perempuan di bawah umur yang menyimpang dari ketentuan umur yang telah diatur. ${ }^{23}$ Namun,

21 Tribun Bolsel, https://manado.tribunnews.com/2019/11/27/hamil-lebih-dulu-jadipenyebab-pengadilan-agama-kantongi-45-permohonan-perkara-dispensasi-nikah, diakses tanggal 6 Januari, 2020.

22 Pengadilan Tinggi Agama Semarang, https://www.pta-semarang.go.id/index.php/ ptajateng/488-pasca-naiknya-batas-umur-perempuan-menikah-perkara-permohonan-

dispensasi-kawin-pada-pengadilan-agama-se-jawa-tengah-naik-286-2-pada-november-2019, diakses tanggal 8 Januari, 2020.

23 Penyimpangan adalah hanya dapat dilakukan melalui pengajuan permohonan dispensasi oleh orang tua dari salah satu atau kedua belah pihak dari calon mempelai kepada Pengadilan 
permohonan untuk mendapatkan dispensasi kawin sebagaimana diatur dalam Pasal 7 ayat (2) itu memiliki batasan bahwa adanya "alasan yang sangat mendesak"24 yang juga disertai dengan "bukti pendukung yang cukup"25.

Aturan mengenai dispensasi kawin diperjelas dalam aturan-aturan turunan dari UU No. 1/1974 yaitu dalam Peraturan Menteri Agama Nomor 3 tahun 1975 tentang Kewajiban Pegawai-Pegawai Nikah dan Tata Kerja Pengadilan Agama dalam Melaksanakan Peraturan Perundang-undangan Perkawinan bagi yang Beragama Islam (selanjutnya ditulis Permenag No. 3/1975) mengenai ketentuan batas usia pernikahan. Dalam Permenag No. 3/1975 diatur apabila usia anak belum mencapai umur minimal pernikahan yang beragama Islam sebagaimana dimaksud UU No. 01/1974, maka dapat dimohonkan dispensasi kawin ke Pengadilan Agama di wilayah tempat tinggalnya. ${ }^{26}$ Adapun bagi mereka yang bukan beragama Islam harus mengikuti ketentuan dari Petunjuk Mahkamah Agung Nomor M.A/Pemb/0807/75 tentang Petunjuk-Petunjuk MA Mengenai Pelaksanaan Undang-Undang Nomor 1 Tahun 1974 dan Peraturan Pemerintah Nomor 9 tahun 1975, yang menyatakan, "wewenang Pengadilan Negeri sebagai Pengadilan Umum untuk memeriksa mengenai perkara-perkara antara mereka yang tidak beragama Islam, yang berbeda agamanya dan berlainan kewarganegaraan."27

Agama bagi mereka yang beragama Islam dan Pengadilan Negeri bagi yang lainnya, apabila pihak pria dan wanita berumur di bawah 19 tahun. Bdk. Penjelasan Pasal 7 ayat 2 UU No. $16 / 2019$.

24 Yang dimaksud dengan "alasan sangat mendesak" adalah keadaan tidak ada pilihan lain dan sangat terpaksa harus dilangsungkan perkawinan. Alasan sangat mendesak adalah kalimat yang bersifat umum dan justru akan menimbulkan multitafsir karena tidak adanya batasan seperti apa yang dapat dikatakan mendesak tersebut. Bdk. Penjelasan Pasal 7 ayat 2 UU No. $16 / 2019$.

25 Yang dimaksud dengan "bukti-bukti pendukung yang cukup" adalah surat keterangan yang membuktikan bahwa usia mempelai masih di bawah ketentuan undang-undang dan surat keterangan dari tenaga kesehatan yang mendukung pernyataan orang tua bahwa perkawinan tersebut sangat mendesak untuk dilaksanakan. Bdk. Penjelasan Pasal 7 ayat 2 UU No. 16/2019. Ketentuan tersebut terdapat dalam Pasal 12 dan Pasal 13 Permenag No. 3/1975.

27 Ketentuan ini diperkuat dengan pasal 49 dan 50 Undang-Undang No. 3 tahun 2006 tentang Perubahan atas Undang-Undang No. 7 tahun 1989 tentang Peradilan Agama, bahwa yang memiliki kompetensi absolut untuk menerima dan memutus serta menetapkan permohonan dispensasi adalah pengadilan agama bagi para pihak yang beragama Islam dan pengadilan negeri untuk pihak selain beragama Islam. 
Sebagai perbandingan, Amerika Serikat (AS) juga menetapkan batas umur menikah untuk warga negaranya. Hukum perkawinan di AS menetapkan 18 tahun untuk dapat memenuhi kategori capacity (kemampuan untuk melangsungkan perkawinan). Khusus untuk negara bagian Nebraska yaitu 19 tahun, dan untuk negara bagian Mississippi yaitu 21 tahun. Apabila calon pasangan tersebut melangsungkan perkawinan kurang dari umur yang ditentukan, maka para pihak diwajibkan untuk meminta izin kepada orang tua masing-masing. ${ }^{28}$ Sementara itu, Inggris menetapkan para pasangan dapat melangsungkan perkawinan jika umurnya telah 18 tahun. Ketentuan tentang pernikahan dini dan dispensasi nikah di Inggris dapat dilihat pada Section 3 ayat (1) dan Section 28 ayat (1) huruf c pada Marriage Act tahun 1946. Dalam ketentuan itu diatur bahwa pada prinsipnya Inggris tidak memperkenankan adanya perkawinan di bawah umur, kecuali adanya izin dari orang tua atau walinya. ${ }^{29}$

Rusia menetapkan batas umur menikah pada warga negaranya yaitu minimal 18 tahun. Jika dalam hal adanya "penyimpangan" terhadap batas minimal umur tersebut, para pasangan yang akan melangsungkan perkawinan diwajibkan mendapatkan izin terlebih dahulu dari Pemerintah Daerah (local goverment). ${ }^{30}$ Baik AS dan Inggris memiliki konsep pemberian izin perkawinan bagi anak di bawah umur yang relatif sama yaitu adanya izin untuk melangsungkan perkawinan dari orang tua masing-masing. Sementara di Rusia anak di bawah batas umur minimal hanya dapat melangsungkan perkawinan dengan terlebih dahulu mendapatkan izin dari pemerintah daerah. Di Indonesia, izin tersebut hanya bisa didapatkan melalui mekanisme pengajuan permohonan dispensasi kawin dari pengadilan. Jika melihat pembahasan ini, maka penelitian ini menyimpulkan bahwa penyimpangan terhadap ketentuan dari batas minimal umur secara hukum dimungkinkan selama, berdasarkan ketentuan hukum yang berlaku, lalu telah didapatkan izin untuk melangsungkan perkawinan itu.

\footnotetext{
Salim HS \& Nurbani, Perbandingan Hukum Perdata, Raja Grafindo, Jakarta, 2014, hlm., 120. Id.

Id.
} 
Dalam praktiknya, sebelum ketua majelis hakim membuat penetapan, ketua majelis mempunyai pertimbangan-pertimbangan apakah permohonan tersebut dapat dikabulkan atau tidak. Dasar pertimbangan majelis hakim adalah sebagai berikut: ${ }^{31}$ Pertama, pemohon yang mengajukan permohonan dispensasi kawin. Majelis hakim di dalam persidangan akan meneliti apakah orang yang mengajukan perkara permohonan dispensasi tersebut berhak mengajukan atau tidak. Kedua, alasan pengajuan permohonan. Pada persidangan majelis hakim menanyakan alasan anak pemohon, kemudian majelis hakim meneliti alasan anak pemohon dengan pemohon di surat permohonannya. Apakah alasan anak pemohon dengan pemohon terdapat persamaan atau tidak. Ketiga, apakah ada larangan perkawinan atau tidak bagi anak pemohon. Bagi calon suami dan calon isteri yang akan melangsungkan pernikahan terdapat halangan atau tidak, sebagaimana yang diatur dalam UU No. 1/1974 jo. UU No. 16/2019.

Pertimbangan lainnya, keempat, kemaslahatan dan kemudharatan. Hubungan dari para pihak yang ingin melangsungkan perkawinan adalah tanpa paksaan dari pihak manapun, artinya bahwa hubungan tersebut memang dikehendaki oleh kedua belah pihak, maka pengadilan dapat mengabulkan permohonan dispensasi tersebut. Hal ini dapat dipahami sebab dikhawatirkan bila tidak segera disatukan dalam ikatan perkawinan yang sah akan menambah dosa dalam konteks nilai-nilai agam dan juga potensial terjadinya perkawinan di bawah tangan yang akan mempersulit proses-proses hukum yang akan terjadi di masa mendatang. Konsekuensi lanjutnya adalah potensial terjadi kesulitan bagi anakanak dari pasangan itu. Dalam konteks sosial kemasyarakatan, pasangan tanpa ikatan perkawinan akan menjadi realita sosial yang tidak dikehendaki di lingkungan masyarakat dimana mereka tinggal.

Selain itu, majelis hakim juga akan mempertimbangkan kelayakan pasangan yang akan melangsungkan perkawinan melalui mekanisme dispensasi kawin. Majelis hakim akan mempertimbangkan antara lain kemampuan, kesiapan,

31 Bagya Agung Prabowo, Pertimbangan Hakim dalam Penetapan Dispensasi Perkawinan Dini Akibat Hamil di Luar Nikah pada Pengadilan Agama Bantul, 20, Jurnal Hukum IUS QUIA IUSTUM, 2013, hlm., 300, 305. 
kematangan pihak-pihak calon mempelai sudah cukup baik mental dan fisik. Majelis hakim mendasarkan penetapan dispensasi kawin atas pertimbangan yang rasional dan memungkinkan untuk memberikan dispensasi kawin kepada pasangan. ${ }^{32}$ Bagya Agung Prabowo menyebutkan bahwa pertimbangan hakim dapat diklasifikasikan menjadi dua yaitu: ${ }^{33}$ pertimbangan hukum, dan pertimbangan keadilan masyarakat. Pertimbangan hukum berarti ketika hakim menjatuhkan penetapannya harus sesuai dengan dalil-dalil dan bukti-bukti hukum yang diajukan. Bukti-bukti yang biasa disyaratkan menurut undang-undang adalah bukti surat dan bukti saksi. Pertimbangan keadilan masyarakat yang dimaksud adalah anggapan bahwa ikatan perkawinan merupakan solusi alternatif bagi penyelesaian masalah sosial yang akan terjadi seperti rasa malu.

\section{Kriminalisasi Perzinaan dalam RKUHP}

Alasan mendasar dari adanya perluasan makna perzinaan dalam RKUHP sebagaimana diatur dalam Pasal 417 ayat (1) tidak dapat ditemukan secara pasti. Terkait itu, pertama-tama perlu dijelaskan mengapa dikatakan terjadi perluasan atas delik perzinaan dan kemudian, melihat logika penyusunan RKUHP, mengapa perluasan itu dapat terjadi. Pertama, adanya perluasan dapat dilihat dengan membandingkan ketentuan dalam KUHP yang sekarang berlaku dan formulasi delik dalam RKUHP. Dalam Pasal 284 diatur bahwa baik laki-laki ataupun perempuan yang dalam ikatan perkawinan melakukan persetubuhan dengan yang bukan pasangannya, diancam dengan pidana penjara paling lama sembilan bulan. ${ }^{34}$ Dengan bahasa lainnya, R. Soesilo menyatakan bahwa yang dimaksud dengan zina adalah persetubuhan yang dilakukan oleh laki-laki atau perempuan yang telah kawin dengan perempuan atau laki-laki yang bukan istri atau

32 Try Sa'adurrahman HM. Kafrawi, Kurniati, Nur Taufiq Sanusi, Tinjauan Hukum Islam dan Hukum Nasional Terhadap Pemberian Dispensasi Nikah Pada Pengadilan Agama Maros, 6, Jurnal Diskursus Islam, 2018, hlm., 326, 339.

33 Bagya Agung Prabowo, supra no. 29.

34 Selain itu, dalam pasal 284 dengan ancaman hukuman yang sama, diberlakukan kepada mereka yang mengetahui perbuatan sebagaimana dimaksud pada bagian ke-1. Baca pasal 284 ke-2. 
suaminya. ${ }^{35}$ Jika ketentuan dan unsur Pasal 284 diperinci, maka terdapat empat syarat agar sebuah perbuatan dapat dikualifikasi sebagai tindak pidana perzinaan.

Pertama, perbuatan persetubuhan itu dilakukan dengan laki-laki atau perempuan yang bukan suami atau istrinya. Kedua, bahwa orang yang melakukan perbuatan zina tidak tunduk pada Pasal 27 KUHPerdata. Ketiga, salah satu pihak atau pasangan yang melakukan persetubuhan tunduk pada Pasal 27 KUHPerdata. Keempat, diketahui bahwa pasangan yang melakukan persetubuhan telah bersuami atau beristri, dan kepada pasangannya dalam persetubuhan itu berlaku ketentuan Pasal 27 KUHPerdata. Jika demikian, sebenarnya dapat diketahui bahwa dasar utama kriminalisasi dari perbuatan zina sebagaimana diatur dalam KUHP yang saat ini berlaku adalah untuk menindak setiap perbuatan perselingkuhan oleh salah satu pasangan yang masih berada dalam suatu ikatan perkawinan yang sah.

Adapun yang terdapat di dalam RKUHP sebagaimana dalam draf per tanggal 14 September 2019, subyek hukum yang dapat dikenai pidana perzinaan terdapat dalam bagian penjelasan Pasal 417 (1). Dalam penjelasan Pasal 417 ayat (1) dinyatakan bahwa yang dimaksud dengan "bukan suami atau istrinya" adalah pertama, laki-laki yang berada dalam ikatan perkawinan melakukan persetubuhan dengan perempuan yang bukan istrinya. Kedua, perempuan yang berada dalam ikatan perkawinan melakukan persetubuhan dengan laki-laki yang bukan suaminya. Ketiga, laki-laki yang tidak dalam ikatan perkawinan melakukan persetubuhan dengan perempuan, padahal diketahui bahwa perempuan tersebut berada dalam ikatan perkawinan. Keempat, perempuan yang tidak dalam ikatan perkawinan melakukan persetubuhan dengan laki-laki, padahal diketahui bahwa laki-laki tersebut berada dalam ikatan perkawina, atau kelima, laki-laki dan perempuan yang masing-masing tidak terikat dalam perkawinan melakukan persetubuhan. Dengan formulasi delik seperti ini, maka jelas ada perluasan makna pelaku perzinaan dari Pasal 284 KUHP dengan Pasal 417 RKUHP.

35 R.Soesilo, Kitab Undang-Undang Hukum Pidana (KUHP) Serta Komentar-Komentarnya Lengkap Pasal Demi Pasal, Politeia, Bogor, 1976, hlm., 209. 
Kedua, terkait dengan mengapa perluasan dilakukan dalam delik perzinaan. Jika melihat pada konstruksi dan unsur delik zina pada Pasal 284 KUHP khususnya terkait subyek hukum yang dapat diancamkan pidana, dapat dilihat bahwa yang fundamental untuk dicegah dan ditindak melalui pasal tersebut adalah perbuatan perselingkuhan dalam pasangan yang berada dalam ikatan perkawinan yang sah. Dengan begitu, pasal ini ingin melindungi ikatan perkawinan dari perbuatan-perbuatan yang dapat mengganggu keharmonisan hubungan suami-istri dalam yang masih sah sebagai pasangan.

Jika merujuk pada konstruksi Pasal 417 ayat (1) termasuk dalam bagian penjelasannya yang memperluas subyek hukum yang dapat dipidana akibat perzinaan, maka dapat disimpulkan bahwa yang ingin dilindungi dengan adanya pasal itu sebenarnya bukan pada ikatan perkawinan sebagaimana semangat dalam Pasal 284 KUHP, melainkan ketertiban di masyarakat. Hal ini dapat dimengerti jika, secara lebih luas, disampaikan semangat utama penyusunan RKUHP, yaitu "untuk menciptakan dan menegakkan konsistensi, keadilan, kebenaran, ketertiban, kemanfaatan, dan kepastian hukum dengan memperhatikan keseimbangan antara kepentingan nasional, kepentingan masyarakat, dan kepentingan individu dalam Negara Kesatuan Republik Indonesia yang berlandaskan pada Pancasila dan Undang-Undang Dasar Negara Republik Indonesia Tahun 1945".36

Dasar penyusunan RKUHP adalah bahwa Indonesia memiliki kompilasi hukum pidana yang sesuai dengan ciri khas dan sesuai dengan karakter masyarakatnya. Para penyusun selalu menekankan perlunya nasionalisasi dan dekolonialisasi hukum pidana milik bangsa Indonesia sendiri. ${ }^{37}$ Dengan paradigma penyusunan demikian, maka sekali lagi dapat dipahami secara khusus

36 Bagian Umum dalam Penjelasan di draf Rancangan Kitab Undang-Undang Hukum Pidana (RKUHP) tanggal 14 September 2019, hlm. 153. Hal ini sendiri menimbulkan pro dan kontra, karena dari sudut pandang hukum pidana, terdapat tegangan antara didahulukannya jaminan atas kepentingan publik dan kepentingan individu.

37 Barda Nawawi Arief, Muladi, dan Eddy OS Hiariej adalah sebagian dari tim perumus yang sering menyampaikan pendapat dan memberikan ekplanasi secara publik tentang upaya penyusunan RKUHP sampai saat ini, termasuk saat pernah terjadi demonstrasi besar mahasiswa menolak disahkannya RKUHP pada akhir tahun 2019. 
pasal mengenai perbuatan perzinaan sengaja diperluas makna dan subyek hukum yang dapat diancamkan pidana. Dengan demikian, dapat juga disimpulkan bahwa pasal perzinaan sebagaimana dimaksud dalam Pasal 417 ayat (1) RKUHP lebih ingin melindungi masyarakat dengan berdasar kepada nilai-nilai moral dan agama yang berlaku di masyarakat.

Kriminalisasi dan perluasan makna serta subyek hukum dalam delik zina ini jelas mempengaruhi konsep dispensasi kawin sebagaimana bahasan utama dalam penelitian ini. Dispensasi kawin akibat hamil di luar ikatan perkawinan diberikan kepada mereka yang ingin melangsungkan perkawinan dengan fakta bahwa pasangan itu atau salah satu di antara mereka masih di bawah umur dan kehamilan yang menjadi dasar utama pengajuan permohonan dispensasi kawin itu adalah karena kehamilan itu diakibatkan persetubuhan oleh laki-laki dan perempuan yang bukan merupakan pasangan dalam ikatan perkawinan yang sah. Fakta kedua itulah yang memiliki titik singgung dengan unsur tindak pidana sebagaimana diatur dalam Pasal 417 ayat (1) RKUHP. Pasangan yang melakukan persetubuhan di luar ikatan perkawinan yang sah adalah subyek hukum yang dapat diancamkan pidana sebagaimana diatur dalam ketentuan Pasal 417 ayat (1) RKUHP.

\section{Dispensasi Kawin sebagai Alasan Penghapus Pidana?}

Dalam teori hukum pidana, terdapat konsep alasan penghapus pidana, dimana dengan kondisi atau ketentuan tertentu, suatu perbuatan pidana dapat untuk tidak dipidana meskipun unsur pidananya telah terpenuhi. Alasan-alasan ini adalah syarat ketat yang hanya dapat diberlakukan karena telah sesuai dengan ketentuan dalam aturan hukum pidana. Dalam KUHP yang saat ini berlaku, perihal alasan penghapus pidana dalam Buku I Bab III tentang hal-hal yang menghapuskan, mengurangkan atau memberatkan pengenaan pidana.

Secara garis besar, berdasarkan KUHP, alasan penghapus pidana antara lain: ${ }^{38}$ tak mampu bertanggung jawab (Pasal 44), daya paksa/overmacht (Pasal

38 Ketentuan Pasal 45 KUHP tentang alasan penghapus pidana "belum umur" sudah dicabut berdasarkan Undang-Undang No. 3 tahun 1997 tentang Peradilan Anak. 
48), melaksanakan ketentuan undang-undang (Pasal 50) dan/atau perintah jabatan (Pasal 51). Selain dari alasan-alasan penghapus pidana yang terdapat dalam KUHP, dikenal juga alasan penghapus pidana di luar KUHP. Dasar dari adanya alasan penghapus pidana di luar KUHP merujuk pada kebiasaan atau rasa keadilan yang diterima di masyarakat sebagai sebuah konsep umum. Alasan penghapus pidana di luar undang-undang adalah tersebut berikut: 1 . Tidak adanya unsur sifat melawan hukum materil; 2 . Adanya consent of the victim atau izin dari orang lain mengenai suatu perbuatan yang dapat dipidana; dan atau 3. Tidak terdapatnya kesalahan sama sekali. ${ }^{39}$

Eddy OS Hiariej memberikan rincian yang lebih lengkap tentang alasanalasan penghapus pidana yang berada di luar KUHP, yaitu izin (adanya consent of the victim), error facti (berkaitan dengan kesesatan dalam kesengajaan), error juris (kesesatan hukum), tidak adanya sifat melawan hukum materil, hak jabatan, dan mewakili urusan orang lain (zaakwaarneming). Selain itu, Hiariej juga mengklasifikasikan adanya alasan penghapus pidana khusus dalam Pasal 221 ayat (2) dan Pasal 310 ayat (3) KUHP serta alasan penghapus pidana putatif yang diartikan manakala "seseorang yang mengira telah berbuat sesuatu dalam daya paksa atau dalam keadaan darurat atau dalam menjalankan undang-undang atau dalam melaksanakan perintah jabatan yang sah, namun kenyataannya tidak demikian". 40

Untuk mendapatkan gambaran yang lebih jelas, berdasarkan Memorie van Toelichting (MvT), alasan penghapus pidana dibagi ke dalam dua golongan, yaitu:

1. Alasan tidak dapat dipertanggungjawabkan seseorang yang terletak pada diri orang itu (inwendige droden van ontoerekenbaarheid); dan

2. Alasan tidak dapat dipertanggungjawabkan seseorang yang terletak di luar orang itu (uitwendige groden van ontoerekenbaarheid). ${ }^{41}$

39 Tri Andrisman, Asas dan Dasar Aturan Umum Hukum Pidana Indonesia serta Perkembangannya dalam Konsep KUHP 2013, 2013, Anugrah Utama Rahardja (Aura), Bandar Lampung, hlm., 111.

40 Eddy OS Hiariej, Prinsip-Prinsip Hukum Pidana, Cahaya Atma Pustaka, Yogyakarta, 2014, hlm., 283-290.

41 Id., hlm., 111. 
Penggolongan MvT ini juga dapat dibaca bahwa baik terkait alasan-alasan penghapus pidana di dalam KUHP maupun diluar KUHP, terdapat kemungkinan adanya dasar tidak dipidannya suatu perbuatan yang berasal dari dalam diri subyek hukum itu ataupun di luar dirinya.

Adapun alasan penghapus pidana di dalam RKUHP diatur dalam Buku I Bagian Kedua tentang Pertanggungjawaban Pidana. Pasal yang secara spesifik mengatur tentang alasan penghapus pidana dimulai dari Pasal 37, Pasal 38, Pasal 39, Pasal 40, Pasal 42, Pasal 43, Pasal 44 sampai Pasal 45. Ketentuan-ketentuan itu dapat dilihat dalam tabel sebagai berikut:

Tabel 2: Alasan penghapus pidana dalam RKUHP

Pasal $37 \quad$ (1) Setiap Orang hanya dapat dimintai pertanggungjawaban atas Tindak Pidana yang dilakukan dengan sengaja atau karena kealpaan.

(2) Perbuatan yang dapat dipidana merupakan Tindak Pidana yang dilakukan dengan sengaja, sedangkan Tindak Pidana yang dilakukan karena kealpaan dapat dipidana jika secara tegas ditentukan dalam peraturan perundang-undangan.

Pasal 38 Setiap Orang yang pada waktu melakukan Tindak Pidana menderita disabilitas mental yang dalam keadaan eksaserbasi akut dan disertai gambaran psikotik dan/atau disabilitas intelektual derajat sedang atau berat tidak dapat dijatuhi pidana, tetapi dapat dikenai tindakan.

Pasal 39 Setiap Orang yang pada waktu melakukan Tindak Pidana menderita disabilitas mental dan/atau disabilitas intelektual pidananya dapat dikurangi dan dikenai tindakan.

\begin{tabular}{|c|c|}
\hline Pasal 40 & $\begin{array}{l}\text { Pertanggungjawaban pidana tidak dapat dikenakan terhadap anak yang pada } \\
\text { waktu melakukan Tindak Pidana belum mencapai umur } 12 \text { (dua belas) tahun. }\end{array}$ \\
\hline Pasal 42 & $\begin{array}{l}\text { Setiap Orang yang melakukan Tindak Pidana tidak dipidana karena: } \\
\text { a. dipaksa oleh kekuatan yang tidak dapat ditahan; atau } \\
\text { b. dipaksa oleh adanya ancaman, tekanan, atau kekuatan yang tidak dapat } \\
\text { dihindari. }\end{array}$ \\
\hline Pasal 43 & $\begin{array}{l}\text { Setiap Orang yang melakukan pembelaan karena terpaksa yang melampaui batas, } \\
\text { yang langsung disebabkan kegoncangan jiwa yang hebat karena serangan atau } \\
\text { ancaman serangan seketika yang melawan hukum tidak dipidana. }\end{array}$ \\
\hline Pasal 44 & $\begin{array}{l}\text { Perintah jabatan yang diberikan tanpa wewenang tidak mengakibatkan hapusnya } \\
\text { pidana, kecuali jika orang yang diperintahkan dengan iktikad baik mengira bahwa } \\
\text { perintah tersebut diberikan dengan wewenang dan pelaksanaannya termasuk } \\
\text { dalam lingkup pekerjaannya. }\end{array}$ \\
\hline Pasal 45 & $\begin{array}{l}\text { Selain alasan pemaaf sebagaimana dimaksud dalam Pasal } 42 \text { sampai dengan Pasal } \\
\text { 44, yang termasuk juga alasan pemaaf adalah: } \\
\text { a. terjadi disabilitas mental dan/atau disabilitas intelektual sebagaimana } \\
\text { dimaksud dalam Pasal } 38 \text {; atau } \\
\text { b. } \quad \text { belum mencapai umur } 12 \text { (dua belas) tahun sebagaimana dimaksud dalam } \\
\text { Pasal } 40 \text { (sudah dicabut). }\end{array}$ \\
\hline
\end{tabular}


Pada prinsipnya, alasan penghapus pidana, baik berupa alasan pembenar maupun alasan pemaaf, yang diatur dalam RKUHP tidak berbeda dengan ketentuan alasan penghapus pidana sebagaimana diatur dalam KUHP yang saat ini berlaku. Baik secara substansi maupun teknis, pengaturan alasan penghapus pidana dalam RKUHP masih mengikuti konstruksi sebagaimana di atur dalam KUHP.

Dengan pembahasan mengenai alasan penghapus pidana termasuk pembagiannya secara terperinci baik berdasarkan KUHP dan RKUHP, pertanyaan akhir yang perlu dijawab adalah apakah konsep dispensasi nikah sebagai dasar penelitian ini dapat dikualifikasikan atau dikonstruksikan sebagai salah satu bentuk alasan penghapus pidana seperti diatur dalam RKUHP. Jika dapat apakah bentuknya berupa alasan pemaaf ataukah alasan pembenar juga merupakan konsep pertanyaan yang akan dibahas dalam bagian ini. Jawaban awal untuk hal ini adalah bahwa dispensasi kawin bisa saja menjadi alasan penghapus pidana. Dasar utamanya adalah adanya consent of the victim atau ijin dari orang lain mengenai suatu perbuatan yang dikualifikasi sebagai perbuatan zina itu sendiri. ${ }^{42}$ Consent of the victim harus ditafsirkan bahwa dari kedua belah pihak tidak ada yang berkeberatan untuk terjadinya tindak pidana perzinaan yang telah dikualifikasi dalam rumusan RKUHP itu. Jika consent of the victim dalam konteks ini harus dikualifikasinya secara lebih mendetil terkait rumusannya sebagai alasan penghapus pidana, maka sesuai dengan karakternya, bahwa perbuataan zina itu sendiri adalah tindak pidana, namun karena terdapat consent of the victim yang bersifat subyektif dari subyek hukum tersebut, alasan penghapus pidana bagi mereka adalah dalam ranah alasan pemaaf.

Persoalan lainnya adalah bahwa dalam persetubuhan, dimana kedua belah pihak mengkehendaki, sebenarnya tidak bisa dinyatakan sebagai perbuatan pidana yang menimbulkan korban (victim). Terkait hal ini juga diperlukan penafsiran perluasan (extensive interpretatie) bahwa sejauh di antara dua belah

42 Penelitian ini melakukan metode penafsiran ekstensif dari konsep yang dijelaskan mengenai adanya consent of the victim atau ijin dari orang lain mengenai suatu perbuatan yang dapat dipidana dalam Tri Andrisman, supra no. 37, hlm., 111. 
pihak tidak terdapat paksaan maka keduanya dapat dikualifikasi sebagai samasama pelaku dan sama-sama korban. Dalam praktik, yang perlu ditekankan bukan pada beban status pelaku melainkan terkait consent atau izin dari keduanya. Jika konstruksinya demikian, maka dispensasi nikah yang diajukan oleh dua belah pihak melalui orang tua/walinya secara sukarela lalu dikabulkan dan dibuktikan dalam sebuah bukti dokumen penetapan pengadilan, dapat dijadikan dasar alasan penghapus pidana dari ancaman hukum Pasal 417 ayat (1) RKUHP. Dalam konteks yang lebih luas, dapat juga dikatakan bahwa pidana zina sebagai delik aduan dan karakternya sebagai delik formil, dapat memperkuat argumentasi mengenai dispensasi kawin sebagai salah satu bentuk alasan penghapus pidana sebagai alasan pemaaf.

\section{Penutup}

Penelitian ini menyimpulkan bahwa dispensasi kawin dapat diajukan sesuai dengan aturan yang terdapat di dalam Pasal 7 ayat (2) UU No. 16/2019. Pasal ini memberi kelonggaran bagi laki-laki dan perempuan di bawah umur yang menyimpang dari ketentuan umur yang telah diatur. Namun, permohonan untuk mendapatkan dispensasi kawin sebagaimana diatur dalam Pasal 7 ayat (2) itu memiliki batasan bahwa adanya "alasan yang sangat mendesak" dalam hal ini dengan sangat terpaksa untuk dilangsungkan perkawinan karena sudah terlanjur hamil di luar ikatan perkawinan. Selanjutnya juga disertai dengan "bukti pendukung yang cukup" yaitu surat keterangan yang membuktikan bahwa usia mempelai masih di bawah ketentuan undang-undang dan surat keterangan dari tenaga kesehatan yang mendukung pernyataan orang tua bahwa perkawinan tersebut sangat mendesak untuk dilaksanakan. Pada praktiknya, majelis hakim mempunyai pertimbangan-pertimbangan untuk mengabulkan permohonan tersebut. Salah satunya ialah kemaslahatan dan kemudharatan. Dalam hal ini, dikhawatirkan bila tidak segera disatukan dalam ikatan perkawinan yang sah akan berpotensi terhadap banyaknya risiko buruk terjadi dimasa yang akan datang. Maka dari itu majelis hakim mengabulkan permohonan dispensasi kawin terhadap kondisi kehamilan di luar ikatan perkawinan. 
Penelitian ini menemukan bahwa dispensasi kawin dapat dijadikan sebagai salah satu bentuk alasan penghapus pidana dalam kualifikasi alasan pemaaf, jika dalam politik hukum pidana penyusunan RKUHP delik perzinaan tetap akan diperluas. Hanya saja, karena tidak ada pasal yang dijadikan "jembatan” untuk mengatur dispensasi kawin secara expressieve verbis maka dalam praktik potensial terjadinya beragam penafsiran. Salah satu dampak paling berbahaya adalah pasangan yang telah mengajukan dispensasi kawin, dan dengan demikian secara otomatis telah mengakui telah melakukan persetubuhan sebelum adanya ikatan perkawinan yang sah, dimana berdasarkan Pasal 417 ayat (1) RKUHP termasuk bentuk tindak pidana perzinaan, dapat saja dijatuhi pidana.

Selain itu, penelitian ini menyimpulkan bahwa perluasan delik pidana perzinaan khususnya dapat dikenakan kepada "laki-laki dan perempuan yang masing-masing tidak terikat dalam perkawinan melakukan persetubuhan" sebagaimana diatur dalam Pasal 417 ayat (1) RKUHP hanya akan memunculkan disharmonisasi antara lapangan hukum dalam hal ini hukum perdata (hukum perkawinan) dan hukum publik (hukum pidana). Penelitian ini menyimpulkan bahwa dalam pembahasan pidana perzinaan dalam RKUHP yang masih terus dilaksanakan perlu mempertimbangkan bahwa dalam keadaan disharmoni antar lapangan hukum ini akan menimbulkan tidak efektifnya penegakan hukum pidana perzinaan itu sendiri. 


\section{Daftar Pustaka}

\section{Buku:}

Ahmad Tholabi Kharlie, Hukum Keluarga Indonesia, Sinar Grafika, Jakarta, 2015.

Eddy OS Hiariej, Prinsip-Prinsip Hukum Pidana, Cahaya Atma Pustaka, Yogyakarta, 2014.

Johnny Ibrahim, Teori dan Metodologi Penelitian Hukum Normatif, Bayumedia Publishing, Malang, 2013.

Peter Mahmud Marzuki, Penelitian Hukum (Edisi Revisi), Prenadamedia Group, Jakarta, 2015.

R. Soesilo, Kitab Undang-Undang Hukum Pidana (KUHP) Serta KomentarKomentarnya Lengkap Pasal Demi Pasal, Politeia, Bogor, 1976.

Salim, HS. Pengantar Hukum Perdata Tertulis (BW), Sinar Grafika, Jakarta, 2011.

Salim HS dan Erlies Septiana Nurbani, Perbandingan Hukum Perdata, Raja Grafindo, Jakarta, 2014.

Sonny Dewi Judiasih et al, Perkawinan Bawah Umur di Indonesia, Refika, Bandung, 2018.

Tri Andrisman, Asas dan Dasar Aturan Umum Hukum Pidana Indonesia serta Perkembangannya dalam Konsep KUHP 2013, Bandar Lampung: Anugrah Utama Rahardja (Aura), 2013.

\section{Jurnal:}

Bagya Agung Prabowo, Pertimbangan Hakim dalam Penetapan Dispensasi Perkawinan Dini Akibat Hamil di Luar Nikah pada Pengadilan Agama Bantul, 20, Jurnal Hukum IUS QUIA IUSTUM. 300, 305, 2013.

Nurul Inayah, Penetapan Dispensasi Nikah Akibat Hamil di Luar Nikah di Pengadilan Agama Yogyakarta Tahun 2010-2015 (Analisis Hukum Acara Peradilan Agama), 10, Al-Ahwal, 178, 179, 2017.

Nur Aisyah, Dispensasi Pernikahan di Bawah Umur pada Masyarakat Islam di Kabupaten Bantaeng, 4, Jurisprudentie. 172, 181, 2017.

Try Sa'adurrahman HM. Kafrawi, Kurniati, Nur Taufiq Sanusi, Tinjauan Hukum Islam dan Hukum Nasional Terhadap Pemberian Dispensasi Nikah Pada Pengadilan Agama Maros, 6, Jurnal Diskursus Islam. 326, 339, 2018.

\section{Internet:}

Badan Kependudukan dan Keluarga Berencana Nasional (BKKBN), https://www.bkkbn.go.id/detailpost/perkawinan-anak-di-indonesiamasih-tinggi.

Jatimnow.com, https://jatimnow.com/baca-20460-hamil-duluan-puluhan-abg-diponorogo-ajukan-dispensasi-nikah.

Pasundanekspres.co, https://pasundanekspres.co/2019/03/213-anak-di-subangsudah-menikah-dispensasi-karena-hamil-duluan.

PTA Semarang, https://www.pta-semarang.go.id/index.php/ptajateng/488pasca-naiknya-batas-umur-perempuan-menikah-perkara-permohonandispensasi-kawin-pada-pengadilan-agama-se-jawa-tengah-naik-286-2pada-november-2019. 
Tribun Bolsel, https://manado.tribunnews.com/2019/11/27/hamil-lebih-dulujadi-penyebab-pengadilan-agama-kantongi-45-permohonan-perkaradispensasi-nikah.

\section{Peraturan Perundang-undangan:}

Undang-Undang R.I., No. 1 Tahun 1974 tentang Perkawinan, L.N.R.I. Tahun 1974 No. 1.

Undang-Undang R.I., No. 16 Tahun 2019 Tentang Perubahan atas Undang-Undang No. 1 Tahun 1974 Tentang Perkawinan L.N.R.I. Tahun 2019 No.186.

Undang-Undang No. 35 tahun 2014 tentang Perubahan atas UU No. 23 tahun 2002 tentang Perlindungan Anak.

Kitab Undang-Undang Hukum Pidana.

Rancangan Kitab Undang-Undang Hukum Pidana tanggal 14 September 2019.

Peraturan Menteri Agama No. 3 tahun 1975 tentang Kewajiban Pegawai-Pegawai Nikah dan Tata Kerja Pengadilan Agama dalam Melaksanakan Peraturan Perundang-undangan Perkawinan bagi yang Beragama Islam.

Petunjuk Mahkamah Agung No. M.A/Pemb/0807/75 tentang Petunjuk-Petunjuk MA Mengenai Pelaksanaan Undang-Undang Nomor 1 Tahun 1974 dan Peraturan Pemerintah Nomor 9 tahun 1975. 